\title{
KIA MANAWANUI
}

\section{Kaupapa Māori Film Theoretical Framework}

\author{
Angela Moewaka Barnes*
}

\begin{abstract}
This paper outlines key categories and elements of Kia Manawanui: Kaupapa Māori Film Theoretical Framework, developed to interrogate film texts and shed light on the processes of Māori film production and environments within which filmmakers operate. Kia Manawanui film theory is informed by diverse expressions of Kaupapa Māori, Indigenous and critical media studies, discussions with Māori filmmakers, theorists and film texts, particularly Ngati (1987), Mauri (1988) and Te Tangata Whai Rawa o Wēniti-The Māori Merchant of Venice (2002). Six key thematic categories emerge: (1) Māori voices, (2) Māori worldviews and concepts, (3) collectivity and relationships, (4) responsibility and accountability, (5) challenge and resistance, and (6) transformation. The framework is not intended to provide a prescriptive or exhaustive list of categories and elements but is distilled from broader parameters to provide a Māori-focused lens that can be applied to film texts and their production contexts.
\end{abstract}

\section{Keywords}

Kaupapa Māori, Indigenous, film, media, representation

\section{Introduction}

As a Māori media researcher, I constantly look to Indigenous theories to inform my work. In the predominantly Eurocentric field of film studies, Indigenous understandings are vital to elucidate and develop understandings about Indigenous media and representations of indigeneity more

* Te Kapotai, Ngāpuhi-Nui-Tonu. Senior Researcher, SHORE \& Whariki Research Centre, College of Health, Massey University, Auckland, New Zealand. Email: A.MwakaBarnes@massey.ac.nz

DOI: 10.20507/MAlJournal.2018.7.1.1 
generally. Kaupapa Māori theory provides a foundation on which to build and legitimate my work, "without genuflection to western academic disciplinary silos" (H. Moewaka Barnes, 2008 , p. 4). Kaupapa is loosely translated as platform, foundation or general principles. Kaupapa Māori theory resonates with my understandings of the world, allowing analyses that reflect who we are as Indigenous peoples and our hopes, experiences and aspirations. To theorise in this way is to make Māori theoretical frameworks, worldviews and aspirations explicit and uncover unequal power relations. Kaupapa Māori theory is not purported to be neutral or objective; my work is profoundly influenced by who I am and where I am from.

Kaupapa Māori is linked to notions of critique, resistance, struggle and a utopian vision of emancipation. Early articulations of Kaupapa Māori as a theory within the academy faced opposition in regard to its legitimacy. Nonetheless, Kaupapa Māori theorists determinedly argued for its relevance and validity (e.g., Leonie Pihama, Linda Tuhiwai Smith, Graham Hingangaroa Smith, Kathie Irwin and Helen Moewaka Barnes), and over time, Kaupapa Māori theory gained national and international significance. Helen Moewaka Barnes (2008) suggests that its transformative power resides in the ability to both challenge and create a space "within and outside the academy, in the face of unequal power relationships" (p. 5). She suggests that, used in this way, "Kaupapa Māori can provide a space for us to work within and fend off colonising theoretical invasions" (p. 5).

This paper discusses the development and application of Kia Manawanui: Kaupapa Māori Film Theoretical Framework (Kia Manawanui), which originated from my doctoral thesis (A. Moewaka Barnes, 2011); it is predominantly informed by three historical films, Ngati (Barclay, 1987), Mauri (Mita, 1988) and Te Tangata Whai Rawa o Wēniti-The Māori Merchant of Venice (Selwyn, 2002), and the filmmakers Barry Barclay, Merata Mita and
Don Selwyn. The paper outlines key domains, with examples provided, to shed light on filmmaking environments, processes of filmmaking, exhibition and film texts through a Māori lens. Kia Manawanui was named by kaumātua Naida Glavish and is both conceptual and practical. Loosely translated, it refers to being alert and listening to intuitions as they provide a steer that then engages with the intellect.

\section{The field of Kaupapa Māori and film}

There is little written research grounded in Kaupapa Māori theory that examines Māori film and filmmaking, and the majority is found in theses; for example, Sam Cruickshank's master's thesis explores Kaupapa Māori and its application to film. Cruickshank identifies a number of principles and elements related to Kaupapa Māori, utilising them in his analytical examination of cinematic representations of Māori men. Although Cruickshank provides areas for examination, his focus is on the representation of Māori men rather than elements of Kaupapa Māori more broadly (Cruickshank, 2002). Grounded in Kaupapa Māori, Leonie Pihama (1994, 2013) has spoken extensively and written about representations of Māori in film. To cite one example, her examination of feature film Boy, directed by Taika Waititi (2010), challenges the absence of references to the effects of colonisation and marginalisation alongside the perpetuation of dominant stereotypes including children left alone and neglected. Textual readings informed by Māori worldviews are provided by Ocean Mercier, for example, by employing Māori concepts including pōwhiri, whanaungatanga and koha to interrogate Boy (Mercier, 2007, 2010) and Taika Waititi's two short films Two Cars, One Night (T. Waititi, 2003) and Tama Tu (T. Waititi, 2005).

Little research and writing has been conducted on the conditions of Mãori filmmaking - the processes and environments—and 
how these may create barriers to or encourage Māori aspirations. Groundbreaking filmmakers Merata Mita and Barry Barclay wrote about their work as filmmakers in Film in Aotearoa New Zealand (Dennis \& Bieringa, 1996). Barclay's (1990/2006) seminal piece Our Own Image is an important record of his experiences as a Māori filmmaker, providing valuable insights and analyses of filmmaking from a Māori base. Documentary filmmaker Kahurangi Waititi (2008) writes about her practical application of Kaupapa Māori in filmmaking, challenging orthodox filmmaking practices that promote an individual focus, as opposed to a collective worldview. This is extended and described in detail in her master's thesis, Applying Kaupapa Māori Processes to Documentary Film (K. Waititi, 2007).

Barclay's notion of Fourth Cinema is also known as Indigenous Cinema. Firmly situated in Aotearoa New Zealand, and emerging from a Māori context, Fourth Cinema is conceptually and practically informed by tikanga and Māori epistemologies, which have resonance with global Indigenous communities. Premised on the thinking that film has the potential to be transformative and uplifting (Barclay, 2003), Fourth Cinema aligns with Kaupapa Māori approaches to film theory in that it validates and affirms Indigenous experiences and identities in a cinematic context, involving both the film text and the filmmaking processes. However, Fourth Cinema is the strategic creation of an Indigenous cinematic category where none previously existed, whereas Kia Manawanui provides a number of ways of interrogating film texts and environments that are grounded in being Māori. During an informal discussion, Barclay (personal communication, 2007) saw a direct resonance between Fourth Cinema and Kaupapa Māori approaches to film theory, as there is a shared language and understanding. However, Fourth Cinema is an emerging category; there is very little written material, and Barclay is the primary author.

\section{Research aims and methods}

To conduct research on Māori film, my intention was to create a Kaupapa Māori film theoretical framework-a space to examine the path forged by Māori filmmakers and their films and to elucidate and develop Māori understandings as a contribution to wider theoretical and media debates about Indigenous representations and creativity. This required an examination of the practical, political and theoretical aspects of Māori filmmaking, including the film texts. In conducting this work, I experienced challenges to my application of Kaupapa Māori to film and was questioned as to whether it fitted in the media studies discipline.

There is a struggling but growing movement in Māori dramatic and documentary filmmaking. Although Māori filmmaking began in the late 1970s and 1980s and has accelerated over the past five years, relatively few dramatic feature films directed and driven by Māori have been made. Kia Manawanui was informed by the work and thinking of a number of Māori working in media production. Specifically, it emerged from the author's engagement with three historical groundbreaking films, Ngati, Mauri and Te Tangata Whai Rawa o Wēniti-The Māori Merchant of Venice, the first dramatic feature films respectively of Barry Barclay, Merata Mita and Don Selwyn. Ngati is described as the first dramatic feature film directed by an Indigenous filmmaker. Mauri was the first, and remains the only, exhibited dramatic feature film solely directed and written by a Māori woman, and Te Tangata Whai Rawa o Wéniti was the first dramatic feature film entirely in te reo Māori. More recently, The Dead Lands (Fraser, 2014) and Moana (Clements \& Musker, 2017) were released in te reo Māori-neither was directed by Māori-and feature film Waru (Grace-Smith et al., 2017) was also released; this was directed by eight Māori women.

Barclay, Mita and Selwyn remain significant contributors to our cinematic history, deliberately offering alternative representations of 
Māori and paving the way for future Māori filmmaking; regrettably, less so for Māori women. Their films offer us unique and transformative cinematic representations of Māori.

As noted above, I drew on a number of theorists in the development of the theoretical framework. I was fortunate to also have formal and informal discussions with a number of Māori theorists and filmmakers, including Barclay and Selwyn, which significantly contributed to the framework's development.

\section{Developing a Kaupapa Māori film theoretical framework}

Drawing on a range of writings, formal and informal discussions, analyses of film texts and my own knowledge, the following key areas related to Māori worldviews, experiences, filmmaking/production and exhibition contexts emerged.

\section{Storytelling}

The craft of storytelling in film has been utilised by Indigenous peoples as a site of resistance in the struggle for justice. Indigenous media can provide a global site where Indigenous peoples imagine and share their aspirations of self-determination (expressed by Māori as tino rangatiratanga and guaranteed by Te Tiriti o Waitangi), experiences and histories: a creative, sustaining and political act. It was Mita's hope that telling these types of stories would create a dent in prevailing misrepresentations (Martin, 1989).

Feature film offers a unique site that Māori voices can inhabit and in which they can give expression to diverse realities and experiences. Here stories of length can be told and shared communally. The drive exists for many Indigenous filmmakers to tell stories about the effects of colonisation; this is potentially unsettling for the coloniser. My master's thesis raised concerns regarding the freedom to talk about our histories on mass media television channels. Some Māori directors I interviewed spoke about the need to strategically and covertly insert issues related to Māori experiences of colonisation. This was attributed to the expectation, based on past experiences, that the broadcaster would either give a clear direction that certain material or references (e.g., the word colonisation) were controversial and should not be included or ask for material to be removed (A. Moewaka Barnes, 2003).

Ella Shohat and Robert Stam (1994) argue that the Eurocentrism of audiences influences cinematic production, where the ideological assumptions of the dominant target audience wield "a kind of indirect hegemony. 'Universal' becomes a codeword for palatable to the Western spectator as the 'spoiled child' of the apparatus" (p. 186). Dominant systems frequently judge Māori stories to be "less" universal or simply not universal. Findings from my master's thesis highlighted the practical ramifications for Māori documentary makers, who were pressured by television commissioners to find and explain the universal themes in their work (A. Moewaka Barnes, 2003). Similar criteria do not appear to be applied to Pākehā stories. The New Zealand Film Commission (NZFC; the main government funder of film) imperative that feature films attract a large audience; assumptions about the types of stories that have broad appeal; and the significant amounts of money involved, including pressure to find overseas distributors and investors, combine to make a Māori agenda challenging. Additionally harder to realise in feature film are works that speak to an Indigenous audience and threaten a unified sense of national identity. For these reasons, Barclay's (1990/2006) notion of "talking in" is vital. It demands the centring of the Indigenous voice that speaks directly to a Māori audience from Māori worldviews and experiences, not explaining itself for the benefit of a non-Māori audience (pp. 74-80).

Although widely understood as entertainment, dramatic feature film brings highly 
selected "realities" to the screen. These representations and stories are an important part of identity formation and contribute to how we see ourselves as Māori. They shape others' perceptions of us locally and globally. As part of my master's study, prior to undertaking a thesis, I researched Māori responses to the films Ngati and The Piano (Campion, 1993), the latter of which was directed and written by Pākehā Jane Campion (A. Moewaka Barnes, 1999). What stood out for me was the role Ngati played in validating Māori identity and culture; participants expressed a sense of pride and feeling uplifted. In contrast, representations of Māori in The Piano resulted in participants feeling uncomfortable, belittled, irritated and embarrassed (A. Moewaka Barnes, 1999). Jani Wilson's doctoral thesis examines audience responses to local films grounded in specific iwi, hapū and whānau connections and understandings. A range of responses to images are recorded, including relief in seeing characters in Once Were Warriors (Tamahori, 1994) that are familiar, but rejecting constructions of Māori as senselessly violent (Wilson, 2013, p. 225).

Gender is an integral part of identity formation. As Kathie Irwin (1992) notes, the experiences of Māori men and women, while sharing similarities, are not the same. Mana tane and mana wahine are important concepts that refer to the strength and dignity of Māori men and women. If we are to be consistent in challenging essentialised representations, gender-driven markers of identity that ignore diversity and complexity need to be scrutinised.

Mana tane challenges dominant and negative constructions of Māori men and, in particular, the negative constructions of Māori as a warrior race. Pihama (2001) argues that this has been seemingly unreflexively internalised by both Māori men and Māori women (p. 253). Director Don Selwyn wanted to offer a range of stories including alternative constructions to Māori men as warriors. His intentions are manifest in the male characters in Te Tangata Whai Rawa o Wèniti, who are represented as urbane, articulate and confident of their place in the world. Combined with the poetic aspects of te reo Māori and Māori culture, Te Tangata Whai Rawa o Wenniti affirms representations of Māori men as mana tane by presenting alternatives to the dominant constructions of Māori hypermasculinity and its associated elements of physicality and violence described by Brendan Hokowhitu (2004, p. 262). Te Tangata Whai Rawa o Wenniti provides a stunning contrast to the stereotypical images of Māori men as warriors and violent perpetuated in films, including Once Were Warriors, The Dead Lands and The Dark Horse (Robertson, 2014).

Mana wahine theory is skilfully articulated by Māori theorists, including Tuhiwai Smith, Pihama, Ani Mikaere, Kathie Irwin, Ngahuia Te Awekotuku and Glynnis Paraha. Pihama (2001) reveals that ongoing colonial discourses and ideologies situate Māori women as inferior and subordinate to men-a practice that must be challenged by both men and women (p. 258). These writings offer ways to examine representations of Māori women in film, how they are positioned and the nature of their roles. For example, it is predominantly the Māori women characters in Merata Mita's feature film Mauri who reinforce connections to the land, tūpuna and wairua. This is conveyed in a powerful shot framing Māori women approaching the marae. Dressed in black, they rise over the crest of a hill as if emerging from the land. They move as one, expressing unity of purpose and the relationship of women to Papatūānuku. As they near the marae, the voice of women as they karanga is given space so it can be heard and experienced. A medium shot reinforces a triangle of women as Kara leads the karanga on the tangata whenua side. The power of these strong cinematic images makes visible and honours the role and status of Māori women in society. Through image and voice, these representations impart the mana of Māori women that pervades the film. 


\section{Being Māori}

Kaupapa Māori theory takes for granted the validity of te reo Māori and the position of importance it holds. The Māori language provides sustenance, a way to conceptualise and affirm our place and experiences in the world; however, fluency in te reo Māori is not a prerequisite to taking a position that validates and advocates for the language.

In a cinematic context, Shohat and Stam (1994) discuss Eurocentric hierarchies of power in language, most evident in Hollywood, where English predominates. Through the telling of "American" stories and those of other cultures in the English language, Hollywood ventriloquises the world. Shohat and Stam explain that the promotion and validation of the English language directly benefits Hollywood and is more generally an expression of Anglo-American power. It indirectly invalidates the languages of Indigenous cultures and diminishes these types of linguistic possibilities in cinematic contexts (pp. 191-193). Hollywood language is then associated with "real" or mainstream cinema just as European languages are perceived to be more cinematic (Shohat \& Stam, 1994, pp. 191-193).

Hierarchies of language and concomitant power relations play out in the cinematic context in Aotearoa New Zealand, where te reo Māori in feature films continues to be severely limited. Te Tangata Whai Rawa o Wenniti, the first feature film in te reo Māori, came about because of Selwyn's dedication and perseverance. His commitment to the language meant that he employed speakers of te reo Māori rather than actors, and so additional rehearsal time was required. Te Tangata Whai Rawa o Wèniti not only honours and legitimises te reo Māori but also establishes it as a cinematic language of depth and beauty.

Along with te reo Māori, tikanga is an explicit part of a Kaupapa Māori approach to production. The groundbreaking television series Tangata Whenua (1974) directed by Barry Barclay introduced many viewers to Māori worldviews and tikanga in depth, with minimal interpretation. The series marked the establishment of Māori creative control in a collaborative environment where the production and technical crew assisted with the development of procedures and practices to incorporate and uphold tikanga, Māori worldviews and concepts (Barclay, 1990/2006, p. 17). These practices, driven by Barclay, broke new ground and established possible workable alternatives for Māori in the craft of filmmaking. For example, Barclay built on and incorporated tikanga and Māori worldviews in the production of Ngati.

As well as driving practice, Māori worldviews and concepts are incorporated into film texts. For example, Barclay (1990/2006) refers to hui as a model that supports the idea of debate as circular rather than linear (p. 14). The hui scene set on the local marae in Ngati represents this concept with long camera takes and pauses; a multitude of diverse voices are given space, regardless of the perceived status of the speakers.

Another key element is wairua, frequently described as a critical component of Kaupapa Māori, residing "at the heart of Kaupapa Māori” (Ratima, 2008, p. 2). In this context, wairua is loosely defined as the spiritual dimension that extends beyond the tangible. Recognising expressions of wairua in films such as Mauri offers rich analyses and ways of understanding, highlighting the need to pay attention to the feelings and emotions experienced by audiences. While hegemonic Western discourse frames Indigenous spirituality as exotic or superstitious, films such as Mauri and Ngati present wairua as the norm, incorporated into everyday understandings and practices. However, understanding and communicating wairua in a cinematic context is complex. 


\section{Representations: Connections and obligations}

Collectivity and responsibility are articulated across the spectrum of Indigenous filmmaking by practitioners and academics. Being part of a greater collective of people, and needing to contribute and challenge, manifests as a desire for transformation, on and off screen.

Notions of collectivity and relationships link to whānau, hapū and iwi and are evident in film practices and texts. Filmmaker Kahurangi Waititi (2008) explains how whānau were central to her filming of kaumātua. Rather than employing a specialist film crew, Waititi's whānau were enlisted and they also participated in interviews with kaumātua. Waititi found that the crew possessed a depth of understanding about the kaupapa that enabled them to skilfully and respectfully negotiate the filming process. Whānau members of kaumātua were encouraged to attend the interviews for support and to ask and answer questions. Waititi challenges orthodox filmmaking practices that promote an individual focus, establish power relationships and clearly delineate roles where only the interviewer is expected to ask questions.

Textually, whānau, hapū and iwi are strong themes in Ngati and Mauri, for example. Ngati reinforces notions of collectivity and relationships by privileging the specific iwi of Ngāti Porou while resonating with iwi and Māori generally. Generations are represented as living together, not always in harmony but with an underlying commitment to an empowering collective and collaborative model. Sitting alongside this are the obligations and loyalties that support the whānau and, by extension, hapū and iwi (Pere, 1988).

Obligations and responsibilities are expressed by many Māori working in film. The three filmmakers in this study frequently spoke of the responsibility to present alternative images of Māori, te reo Māori and tikanga on screen. Responsibility extends to the protection of Māori images; Barclay, in particular, advances the concept of kaitiakitanga or guardianship, referring to films that honourably capture Māori images as taonga (Barclay, 2005).

Responsibility and accountability in part emerge from the "burden of representation" or negative effects of representation. Shohat and Stam (1994) argue that this burden unjustly sits with the oppressed (p. 183). They refer to Memmi's notion of the "mark of the plural", which describes the characterisation of the colonised (with their inherent depravity and deviance) by the coloniser as a collective undifferentiated entity; therefore, any negative individual actions by a member of that group are representative of the entire group's perceived deviance (Memmi, 2000, p. 151). As a result, the oppressed group becomes "sorely overcharged with allegorical meanings", making it an almost unbearable experience (Shohat \& Stam, 1994, p. 182). Representations of the dominant group do not suffer the same condition, and an aberrant individual member is not seen to be representative of the group as a whole. It suggests that negative stereotyping generally is hurtful, but representations do not all "exercise the same power in the world" (Shohat \& Stam, 1994, p. 182).

Beverley Singer (2001), a Native American film director and writer, expresses concern about the stereotypical nature of representations in all areas of the media, including the earliest representations of Native Americans as savage and heathen (p. 1). As a result of such depictions, Indigenous communities have debated and challenged filmic representations that perpetuate dominant discourses and stereotypes, understanding that "something vital is at stake” (Shohat \& Stam, 1994, p. 181).

The effects of colonial discourses and unequal power relationships led Māori theorists, including Pihama, Tuhiwai Smith and Hingangaroa Smith, to call for "theorising back", "writing back" and "talking back" to theories that serve the interests of the dominant group (Pihama, 2001, pp. 72-75; Smith, 1999, p. 7). This distinctly Māori space centres the experiences 
and epistemologies of the Indigenous, critiques colonisation and develops strategies for selfdetermination (Smith, 1999, p. 7). Resistance and challenge in the form of "writing back" and "talking back" are equally applicable to a Kaupapa Māori film theoretical approach.

To further reveal power relations in film, I draw on feminist theory, in particular, notions of the "gaze". Related variations of the gaze emerging from other studies, including the ethnographic gaze and the imperial gaze, reveal relationships between power and visuality that are distinct, with their own ideological and institutional origins. In her examination of the imperial gaze, Ann Kaplan (1997) argues that it "reflects the assumption that the white Western subject is central, much as the male gaze assumes the centrality of the male subject" (pp. 78-79). Gaze, in the context of a Kaupapa Māori film theoretical approach, emerges from a distinctly Indigenous place where Māori have been subjected to persistent and multiple forms of the colonial or Pākehā gaze. In Ngati, Barclay (1990/2006) deliberately flipped the gaze to reveal and disrupt power relationships (p. 54). This is established in an early scene when Greg Shaw, depicted as a young male Pākehā character, arriving in a rural, largely Māori community, is the observed outsider, establishing the centrality and agency of Māori in the film.

\section{Māori access to filmmaking}

In cinematic environments, analysis of power operating through structures, policies and institutional practices that affect Māori filmmaking is required to reveal and develop Māori-focused solutions. Māori advocacy for the Crown to meet its Te Tiriti o Waitangi obligations is particularly evident in broadcasting but is equally relevant to film. Barclay argued that, for a truly Indigenous voice to develop, Māori must not only control funding on specific projects but also control wider decision-making on how funding is distributed to Māori (Te Ahi Kaa,
2007). The Waitangi Tribunal claim WAI 748 led by Barclay and lodged with the Tribunal in 1998 charged the NZFC with not meeting its obligations under the Treaty. At the time of writing this paper, it is understood that the claim remains lodged with the Tribunal.

To progress Māori access to funding, an early proposal to the NZFC to establish a Māori film fund articulated the need for a strong Māori voice and the opportunity to speak for ourselves, "lest others speak for us" (Gauthier, 2008, p. 71). After tireless advocacy by Māori involved in media production, Te Paepae Ataata was established to nurture and fund the development of Māori feature films. I attended the 2007 formal launch of Te Paepae Ataata, where Barclay announced with optimism and good faith that "the house is now restored" and he would not pursue WAI 748. This fund no longer exists; an NZFC Māori filmmaking strategy is currently in development.

\section{Kia Manawanui: Kaupapa Māori Film Theoretical Framework}

Key concepts emerging from the literature, discussions and historical film texts outlined previously were analysed to inform the development of the Kia Manawanui framework. The process was iterative, alternating between the concepts and their practical application to film texts. Six key themes emerged: (1) Māori voices, (2) Māori worldviews and concepts, (3) collectivity and relationships, (4) responsibility and accountability, (5) challenge and resistance, and (6) transformation.

Each theme contains sub-themes; they are not positioned hierarchically. Although the thematic categories and elements are separated out for analytical purposes and proved to be a useful and practical way of applying the framework, they are interconnected. For example, there are strong links between theme 4 (responsibility and accountability) and theme 5 (challenge and resistance). Don Selwyn, for example, spoke 
about his responsibility to challenge dominant representations of Māori men, and accountability permeates both the filmmaking processes and the stories Selwyn, Barclay and Mita chose to tell. Unlike some articulations of Kaupapa Māori theory, te reo Māori and tikanga are separated (Pihama, 2001). This separation is not intended to diminish the interconnectedness of language and culture but allows focused analyses of these two elements in film texts.

The framework offers ways to examine film texts by theming what emerged from applying a Kaupapa Māori lens and the extent to which films progressed these concepts. It is about arriving at insights and understandings rather than a way of measuring the authenticity of a film. The intention of Kia Manawanui is also to shed light on filmmaking environments in Aotearoa New Zealand, including funding, processes of filmmaking and exhibition alongside aspirations of Māori filmmakers. Table 1 outlines key themes and elements with broad questions that can be asked as part of the analytical process. A comprehensive version is available in the doctoral thesis (A. Moewaka Barnes, 2011).

\section{Key themes}

\section{Māori voices}

The theme of Māori voices encompasses multiple expressions, including telling, legitimating and centring our stories, our histories, te reo Māori and the diversity of Māori identity. It raises questions of address and asks who is the film primarily speaking to and who is the imagined audience.

\section{Māori worldviews and concepts}

The theme of Māori worldviews and concepts relates to their incorporation in filmmaking practices and film texts, asking how they are represented in film texts: normalised or exoticised, central or peripheral? An examination of filmmaking practices grounded in tikanga and Māori worldviews does not suggest there is a set of rules to follow nor is it conducted to establish a hierarchy of Māori film practices. It is used here to cast light on how Māori filmmakers may choose to work and their inevitable struggles and compromises.

\section{Collectivity and relationships}

Applicable to filmmaking and the film texts, the theme of collectivity and relationships emphasises the importance of the collective, which includes whānau, hapū and iwi, without diminishing the role of the individual. The meaning of whānau is not premised on heteronormative behaviours, and it challenges the Eurocentric construction of the nuclear family. It implies support, sustenance, mutual respect, loyalty, obligations and responsibilities. These complex structures and relationships offer a collective and collaborative model that is potentially transformative.

\section{Responsibility and accountability}

The element of responsibility and accountability relates to the filmmakers rather than the films. It examines expressions of responsibility and accountability as articulated and/or practised by Māori filmmakers, for example, to provide alternative representations. These obligations may be shared by Indigenous peoples globally. It includes analyses of the struggles and achievements entailed in fulfilling Māori aspirations related to filmmaking, including kaitiakitanga of the Māori image.

\section{Challenge and resistance}

Challenging power and privilege is integral to multiple aspects of film analysis, in particular, the intentions of Māori filmmakers and the film texts. Providing counter hegemonic representations resists and disrupts power relationships; 
TABLE 1 Kia Manawanui: Kaupapa Māori Film Theoretical Framework

\begin{tabular}{|c|c|c|c|}
\hline $\begin{array}{l}\text { Thematic } \\
\text { categories }\end{array}$ & Central concerns & $\begin{array}{l}\text { Elements may } \\
\text { include }\end{array}$ & Broad questions \\
\hline (1) Māori Voices & $\begin{array}{l}\text { Where the Māori } \\
\text { voice is located } \\
\text { and the nature of } \\
\text { that voice. } \\
\text { Audience } \\
\text { responses. }\end{array}$ & $\begin{array}{l}\text { Te reo Māori, } \\
\text { storytelling, } \\
\text { histories, } \\
\text { experiences, } \\
\text { mana wahine, } \\
\text { mana tane and } \\
\text { identity. }\end{array}$ & $\begin{array}{l}\text { Who is telling the story? Is the } \\
\text { Māori voice centred? Does the } \\
\text { film reflect Māori experiences, } \\
\text { histories, aspirations and } \\
\text { identity in their diversity and } \\
\text { complexity? } \\
\text { Does the film primarily speak } \\
\text { to a Māori audience? How } \\
\text { do audiences respond, e.g., } \\
\text { emotions, feelings, behaviours? }\end{array}$ \\
\hline $\begin{array}{l}\text { (2) Māori } \\
\text { Worldviews and } \\
\text { Concepts }\end{array}$ & $\begin{array}{l}\text { How Māori } \\
\text { worldviews and } \\
\text { concepts are } \\
\text { represented in } \\
\text { film. } \\
\text { Māori } \\
\text { worldviews } \\
\text { and practices in } \\
\text { filmmaking. }\end{array}$ & $\begin{array}{l}\text { Māori concepts, } \\
\text { worldviews and } \\
\text { practices, e.g., } \\
\text { tikanga, wairua. }\end{array}$ & $\begin{array}{l}\text { How does the film represent } \\
\text { Māori worldviews and concepts? } \\
\text { Is it central to the film or } \\
\text { peripheral? Does it honour and } \\
\text { legitimate or does it marginalise, } \\
\text { exoticise or appropriate? } \\
\text { Are Māori worldviews expressed } \\
\text { in filmmaking practices and } \\
\text { how is this manifested? What } \\
\text { are the challenges, struggles and } \\
\text { solutions associated with this? }\end{array}$ \\
\hline $\begin{array}{l}\text { (3) Collectivity } \\
\text { and Relationships }\end{array}$ & $\begin{array}{l}\text { How notions of } \\
\text { collectivity and } \\
\text { the associated } \\
\text { roles and } \\
\text { obligations are } \\
\text { expressed in film. } \\
\text { The application } \\
\text { of collectivity and } \\
\text { the nature of the } \\
\text { relationships in } \\
\text { filmmaking. }\end{array}$ & $\begin{array}{l}\text { Social structures } \\
\text { (whānau, } \\
\text { hapū and iwi), } \\
\text { collectivity, } \\
\text { kotahitanga and } \\
\text { connectivity } \\
\text { (tūpuna, } \\
\text { whanaungatanga } \\
\text { and whakapapa). }\end{array}$ & $\begin{array}{l}\text { Does the film express notions } \\
\text { of individuality or collectivity? } \\
\text { How does the film express } \\
\text { collectivity and inter- } \\
\text { relationships? } \\
\text { What role do Māori concepts of } \\
\text { collectivity and connectivity play } \\
\text { in advancing Māori aspirations } \\
\text { in film? }\end{array}$ \\
\hline $\begin{array}{l}\text { (4) Responsibility } \\
\text { and Accountability } \\
\text { (relates to } \\
\text { filmmakers rather } \\
\text { than films) }\end{array}$ & $\begin{array}{l}\text { Examining } \\
\text { expressions of } \\
\text { responsibility and } \\
\text { accountability } \\
\text { as articulated } \\
\text { by Māori } \\
\text { filmmakers. }\end{array}$ & $\begin{array}{l}\text { Wider } \\
\text { obligations and } \\
\text { accountabilities } \\
\text { that may extend } \\
\text { to Indigenous } \\
\text { peoples globally. }\end{array}$ & $\begin{array}{l}\text { What concerns are raised by } \\
\text { filmmakers who identify as } \\
\text { Māori? What motivations/ } \\
\text { aspirations are articulated by the } \\
\text { filmmaker? } \\
\text { Are notions of accountability } \\
\text { and responsibility expressed? }\end{array}$ \\
\hline
\end{tabular}




\begin{tabular}{|c|c|c|c|}
\hline $\begin{array}{l}\text { Thematic } \\
\text { categories }\end{array}$ & Central concerns & $\begin{array}{l}\text { Elements may } \\
\text { include }\end{array}$ & Broad questions \\
\hline \multirow[t]{3}{*}{$\begin{array}{l}\text { (5) Challenge and } \\
\text { Resistance }\end{array}$} & $\begin{array}{l}\text { Power dynamics } \\
\text { in the filmmaking } \\
\text { environment. } \\
\text { The ways in } \\
\text { which challenge } \\
\text { and resistance are } \\
\text { articulated by the } \\
\text { filmmaker. } \\
\text { How challenge } \\
\text { and resistance } \\
\text { are represented in } \\
\text { film. }\end{array}$ & \multirow[t]{3}{*}{$\begin{array}{l}\text { Colonisation, } \\
\text { racism, Te Tiriti } \\
\text { o Waitangi, self- } \\
\text { determination, } \\
\text { power and } \\
\text { counter- } \\
\text { hegemonic } \\
\text { representations. }\end{array}$} & $\begin{array}{l}\text { What power dynamics are } \\
\text { occurring in the filmmaking } \\
\text { environments? Who benefits } \\
\text { from Crown funding? How do } \\
\text { dominant structures and funding } \\
\text { policies support or hinder stories } \\
\text { told and driven by Māori? What } \\
\text { stories get told? Are Māori } \\
\text { cinematic aspirations addressed } \\
\text { within the wider issues of } \\
\text { Crown obligations, Te Tiriti } \\
\text { and Māori status as tangata } \\
\text { whenua? }\end{array}$ \\
\hline & \multirow{2}{*}{$\begin{array}{l}\text { How challenge } \\
\text { and resistance } \\
\text { are represented in } \\
\text { film. }\end{array}$} & & $\begin{array}{l}\text { What struggles and } \\
\text { achievements are articulated } \\
\text { by Māori filmmakers involved } \\
\text { in realising Māori cinematic } \\
\text { aspirations? }\end{array}$ \\
\hline & & & $\begin{array}{l}\text { How does the film depict and/or } \\
\text { challenge issues of oppression, } \\
\text { colonisation and racism? How } \\
\text { does it engage with, challenge } \\
\text { or disrupt hegemonic discourses } \\
\text { and representations? }\end{array}$ \\
\hline \multirow[t]{2}{*}{ (6) Transformation } & \multirow[t]{2}{*}{$\begin{array}{l}\text { The } \\
\text { transformative } \\
\text { potential of film. }\end{array}$} & \multirow{2}{*}{$\begin{array}{l}\text { Solutions, } \\
\text { representations } \\
\text { that are } \\
\text { liberatory, } \\
\text { validating and } \\
\text { inspirational. } \\
\text { Decolonisation } \\
\text { and Indigenising } \\
\text { the screen. }\end{array}$} & $\begin{array}{l}\text { Does the film offer liberatory } \\
\text { and inspirational representations } \\
\text { of Māori? }\end{array}$ \\
\hline & & & $\begin{array}{l}\text { Does it challenge us to rethink } \\
\text { internalised hegemonies? How is } \\
\text { this expressed by the filmmaker } \\
\text { or manifested in the film text? }\end{array}$ \\
\hline
\end{tabular}

for example, inverting the colonial gaze is a challenge frequently presented by Māori film. It is directly relevant to the film texts, through an examination of the camera's point-of-view, narrative, character interactions and stances, for example.

Tino rangatiratanga is not separated out from Te Tiriti o Waitangi in the framework because this highlights the wider issues of selfdetermination and sovereignty that sit alongside the Crown's responsibilities and obligations to Māori as tangata whenua. Social, political and economic structures and processes may not only produce inequities but also reproduce inequities by neglect or absence of conditions. A critique of power examines who benefits from films that tell Māori stories. For example, where do Māori sit in a film's production structure? Are Māori in decision-making roles and did Māori involvement lead to further opportunities to progress both individual aspirations and, more broadly, Māori filmmaking aspirations? What opportunities and supports are available to Māori women filmmakers? 


\section{Transformation}

Film that speaks, names, validates and claims from a Māori base can be transformative for an audience, both Māori and non-Māori. This is relevant to the shaping of Māori identities, including the identities of our children and youth. A Kaupapa Māori cinematic space has the potential to transform notions of the Māori place in film and filmmaking environments.

\section{Discussion}

Originally, I developed Kia Manawanui to offer understandings in media studies centred in a Māori cinematic gaze. I was highly selective in my theoretical referencing in the textual analyses of the three historical films in order to privilege and test the framework. This is also the result of not wanting to force other theories to fit when Kaupapa Māori works perfectly well because it articulates Māori understandings and experiences, offering both richness and complexity of analyses. The framework clarified my own approach to film studies and the requirement that it critique power and dominant hegemonic discourses and representations.

It was always my intention to build on Kia Manawanui, and during its development I applied it to compare news coverage of Waitangi Day on mass media and Māori Television. The key themes illuminated the differences in approach between mass and Māori news television. It illustrated how Māori news represented diverse Māori worldviews and experiences, whereas mass television focused on the absence of "protester" violence where Māori involvement was implicit. This assisted me in the framework's refinement.

More recently, I extended its application to include audience responses to local television dramas under the theme "Voices". Two key findings emerged. Firstly, when viewing the material alongside a Pākehā audience, some Māori participants expressed increased feelings of unease when watching dramas that perpetuated negative constructions of Māori. The participants felt that these constructions reinforced negative views held by Pākehā, affecting how they, as Māori, negotiated and immediately responded to the drama. Viewing the same drama with Māori appears to help mitigate these affects. Secondly, some Māori participants expressed feelings of guilt when they found excerpts amusing while they simultaneously cringed at Māori portrayals that reinforced dominant representations. These responses reveal how, as Māori, we frequently feel conflicted in our emotional responses and negotiate our feelings within wider contexts. Questions are raised about the extent to which these dramas progress particular types of representations that, within a local and global context, people may interpret as the way Māori are. So few Māori stories get told that there is little diversity available and each representation takes on a particular level of power-unlike the dominant culture, who have the privilege to tell, hear and see a multitude of stories.

Kaupapa Māori film theory, as discussed here, embraces the diversity and complexities of being Māori and our experiences and understandings of the world. Because of this diversity and the expansiveness of Māori concepts, the potential of Kaupapa Māori is also vast and should not be limited. Kaupapa Māori film theory is an evolving field and my intention, in contributing to its development, is not to be definitive or prescriptive. Neither is it meant to provide a checklist or set of criteria that films must meet to establish a Māori "authenticity" or be called Māori.

\section{Conclusions}

Kia Manawanui encompasses an analysis of both filmmaking environments and film texts, offering understandings informed by Māori worldviews and experiences. Interrogating film texts in isolation from the environments in 
which they are produced and received is unlikely to uncover the complexities of film production, including the numerous restrictions of state and commercial imperatives that may or may not be consistent with the aspirations of Māori filmmakers. However, as history reveals, these tensions have been opportunistically and strategically responded to by Māori filmmakers in order to produce programmes and films driven by Māori agendas and creative visions. My hope is that the application of Kia Manawanui to a cinematic and televisual context will further develop and legitimise Māori-centred film theory and Māori filmmaking.

Kaupapa Māori has resonance with other Indigenous peoples, and conversations suggest that a Kaupapa Māori approach to film will be of relevance and by extension contribute to and support Indigenous media theories and filmmaking globally. With resistance comes hope, signalling the celebratory aspect of Kaupapa Māori film theory and the work, sense of purpose and commitment of many Indigenous filmmakers. With this in mind, the act of Indigenous filmmaking is a celebration not only of survival but also of creativity and achievement in adverse circumstances.

\section{Acknowledgements}

Don Selwyn (1935-2007), Merata Mita (19422010), Barry Barclay (1944-2008) and their whānau for their generous contributions to my studies. I thank others who gave generously of their time, including Māori filmmakers and theorists; Naida Glavish, who named the theoretical framework; Helen Moewaka Barnes, who provided valuable insights that contributed to the development of Kia Manawanui; and Tim McCreanor for his feedback on my drafts. Supported by the Marsden Fund Council from government funding, administered by the Royal Society of New Zealand (contract MAU 1307: Affect and Identity in Contemporary Television
Drama) and Ngā Pae o te Maramatanga. Ka nui te mihi ki ā koutou katoa.

\section{Glossary}

\begin{tabular}{|c|c|}
\hline hapū & sub-tribe, kinship group \\
\hline hui & a gathering or meeting \\
\hline iwi & nation, tribe \\
\hline kaitiakitanga & guardianship \\
\hline karanga & call of welcome \\
\hline kaumātua & $\begin{array}{l}\text { respected elder (male or } \\
\text { female) }\end{array}$ \\
\hline kaupapa & $\begin{array}{l}\text { topic, platform, general } \\
\text { principles, underlying } \\
\text { base }\end{array}$ \\
\hline & gift \\
\hline
\end{tabular}

kotahitanga Māori unity. Historically connected to iwi unity mana authority, prestige, related to Māori sovereignty and power

marae gathering place, ancestral meeting place

Pākehā people of European origin

Papatūānuku Earth mother pōwhiri formal welcome, processes of encounter tane male tangata whenua hosts, Indigenous peoples of the land taonga treasure, something that is highly prized te reo Māori Māori language Te Tiriti o a founding document first Waitangi signed in 1840 by hapū and the Crown

tikanga

tino Māori protocols, practices or processes self-determination rangatiratanga tūpuna ancestors wahine female wairua spiritual essence 


$\begin{array}{ll}\text { Waitangi Day } & \begin{array}{c}\text { a national holiday } \\ \text { on } 6 \text { February that } \\ \text { commemorates the } \\ \text { signing of Te Tiriti o } \\ \end{array} \\ & \text { Waitangi } \\ \text { genealogy, connections } \\ \text { whakapapa } & \text { extended family groupings } \\ \text { whānau } & \text { and structures } \\ \text { whanaungatanga } & \text { relationships, collectivity }\end{array}$

\section{References}

Barclay, B. (Dir.). (1974). Tangata whenua [Television series]. New Zealand: Pacific Films.

Barclay, B. (Dir.). (1987). Ngati [Motion picture]. New Zealand: Pacific Films.

Barclay, B. (2003, Winter). Celebrating Fourth Cinema. Illusions, 35, 7-11.

Barclay, B. (2005). Mana tūturu: Māori treasures and intellectual property rights. Auckland, New Zealand: Auckland University Press.

Barclay, B. (2006). Our own image. Auckland, New Zealand: Longman Paul. (Original work published 1990)

Campion, J. (Dir.). (1993). The piano [Motion picture]. Australia: Jan Chapman Productions.

Clements, R., \& Musker, J. (Dir.). (2017). Moana (te reo Māori version) [Motion picture]. United States: Walt Disney Animation.

Cruickshank, S. (2002). From a scary black bastard (Unpublished master's dissertation). Auckland, New Zealand: University of Auckland.

Dennis, J., \& Bieringa, J. (Eds). (1996). Film in Aotearoa New Zealand. Wellington, New Zealand: Victoria University Press.

Fraser, T. (Dir.). (2014). The dead lands (2014). New Zealand: General Film Corporation.

Gauthier, J. (2008). "Lest others speak for us": The neglected roots and uncertain future of Maori cinema in New Zealand. In P. Wilson \& M. Stewart (Eds.), Global indigenous media: Cultures, poetics, and politics (pp. 58-73). Durham, NC: Duke University Press. http://doi.org/cgn7

Grace-Smith, B., Kaa, C., Gardiner, A., Wolfe, K., Cohen, C., Maihi, R., . . . Simich-Pene, A. (Dir.). (2017). Waru [Motion picture]. New Zealand: Brown Sugar Apple Grunt Productions.

Hokowhitu, B. (2004). Tackling Māori masculinity: A colonial genealogy of savagery and sport. The Contemporary Pacific, 16(2), 259-284. http:// doi.org/fpt78n

Irwin, K. (1992). Towards theories of Māori feminism. In R. Du Plessis (Ed.), Feminist voices: Women's studies texts for Aotearoa/New Zealand (pp. 1-21). Auckland, New Zealand: Oxford University Press.

Kaplan, E. A. (1997). Looking for the other: Feminist film and the imperial gaze. New York, NY: Routledge.

Martin, H. (1989, October 14). Through a Maori lens. Listener, pp. 30-31.

Memmi, A. (2000). Racism. Minneapolis, MN: University of Minnesota Press. 
Mercier, O. (2007). Close encounters of the Māori kind: Talking interaction in the films of Taika Waititi. New Zealand Journal of Media Studies, 10(2), 37-51. http://doi.org/ccts

Mercier, O. (2010, Winter). "Welcome to my interesting world": Powhiri styled encounter in Boy. Illusions, 42, 3-7.

Mita, M. (Dir.). (1988). Mauri [Motion picture]. New Zealand: Awatea Films.

Moewaka Barnes, A. (1999). [Unpublished master's research essays]. Department of Film, Television and Media Studies, University of Auckland, New Zealand.

Moewaka Barnes, A. (2003). Kanohi kite a te Maori: Maori documentaries, negotiating the complexities of television in Aotearoa (Unpublished master's thesis). University of Auckland, New Zealand.

Moewaka Barnes, A. (2011). Ngā kai para $i$ te kahikātoa: Māori filmmaking, forging a path (Unpublished doctoral thesis). University of Auckland, New Zealand.

Moewaka Barnes, H. (2008). Arguing for the spirit in the language of the mind: A Māori practitioner's view of research and science (Unpublished doctoral thesis). Massey University, Auckland, New Zealand.

Pere, R. R. (1988). Te Wheke: Whaia te maramatanga me te Aroha. In S. Middleton (Ed.), Women and education in Aotearoa (pp. 6-19). Wellington, New Zealand: Allen and Unwin.

Pihama, L. (1994). Are films dangerous? A Maori woman's perspective on The Piano. Hecate, 20(2), 239-242.

Pihama, L. (2001). Tīhei mauri ora: Honouring our voices: Mana wahine as a kaupapa Māori theoretical framework (Unpublished doctoral thesis). University of Auckland, New Zealand.

Pihama, L. (2013). A short commentary on Boy. Media Studies Journal of Aotearoa, 13(1), 97-101. http://doi.org/cgn8
Ratima, M. (2008). Making space for Kaupapa Māori within the academy. MAI Review, 1, 1-3. Retrieved from http://www.mai.ac.nz/index. php/MR/article/viewFile/124/122

Robertson, J. N. (Dir.). (2014). The dark horse [Motion picture]. New Zealand: Four Knights Film.

Selwyn, D. (Dir.). (2002). Te tangata whai rawa o Wēniti-The Maori merchant of Venice [Motion picture]. New Zealand: He Taonga Films.

Shohat, E., \& Stam, R. (1994). Unthinking Eurocentrism: Multiculturalism and the media. London, England: Routledge.

Singer, B. (2001). Wiping the war paint off the lens. Minneapolis, MN: University of Minnesota Press.

Smith, L. (1999). Decolonizing methodologies: Research and indigenous peoples. London, England: Zed.

Te Ahi Kaa. (2007, December 2). Interview with Barry Barclay [Radio broadcast]. In Te Abi Kaa. Wellington, New Zealand: Radio New Zealand.

Tamahori, L. (Dir.). (1994). Once were warriors [Motion picture]. New Zealand: Communicado.

Waititi, K. (2007). Applying Kaupapa Māori processes to documentary film (Unpublished master's dissertation). University of Waikato, Hamilton, New Zealand.

Waititi, K. (2008). Māori documentary film: Interiority and exteriority. Mai Review, 1. Retrieved from http://www.review.mai.ac.nz/index.php/MR/ article/viewFile/116/132

Waititi, T. (Dir.). (2003). Two cars, one night [Motion picture]. New Zealand: Blueskin Films and Defender Films.

Waititi, T. (Dir.). (2005). Tama tū [Motion picture]. New Zealand: Whenua Films.

Waititi, T. (Dir.). (2010). Boy [Motion picture]. New Zealand: Whenua Films.

Wilson, J. K. T. (2013). Whānau and korero-based film analysis (Unpublished doctoral thesis). University of Auckland, New Zealand. 